\title{
Hubungan Peran Orang Tua dan Pola Asuh Makan terhadap Perkembangan Balita
}

\author{
Ernita Prima Noviyani ${ }^{1}$, Irma Jayatmi ${ }^{2}$, Irma Herliana ${ }^{3}$ \\ ${ }^{1,2,3}$ Sekolah Tinggi Ilmu Kesehatan Indonesia Maju \\ Jln. Harapan Nomor 50, Lenteng Agung - Jakarta Selatan 12610 Telp: (021) 78894045 \\ Email :ernitaprima.stikim@gmail.com;irma.jayatmi@stikim.ac.id;herlianaws@gmail.com
}

\begin{abstract}
Abstrak
Penelitian ini bertujuan mengetahui hubungan pola asuh orang tua dan pola asuh makan terhadap perkembangan balitadi Puskesmas Kecamatan Pasar Minggu Jakarta Selatan Tahun 2017. Jenis penelitian yang digunakan dalam penelitian ini adalah kuantitatif dengan pendekatan rancangan desain Cross Sectional.Sampel yang diambil adalah seluruh total populasi yang ada yaitu seluruh ibu-ibu yang mempunyai anak usia balita Puskesmas Kecamatan Pasar Minggu Jakarta Selatan Tahun 2017 sebanyak 107 orang. Hasil penelitian menunjukkan variabel peran orang tua diperoleh p value sebesar 0,019 , variabel pola asuh makan diperoleh $\mathrm{p}$ value sebesar 0,011 , maka dapat disimpulkan bahwa ada hubungan antara peran orang tua dan pola asuh makan dengan perkembangan Balita di Puskesmas Kecamatan Pasar Minggu Jakarta Selatan Tahun 2017. Disimpulkan bahwa peran orangtua berpengaruhdalam perkembangan yaitu membentuk kemampuan dan keterampilannyadalam mengasuh dan mendidik anakanaknya. Sedangakan pola makan memiliki hubungan dengan perkembangan anak dimana orang tua yang memiliki tingkat pengetahuan yang baik tentang pola makan akan mampu untuk memantau dan melatih anak untuk perkembangan dengan optimal sehingga jika terjadi kelainan tumbuh kemang pada anak dapat dideteksi secara dini. Disarankan untuk orang tua, harus selalu memberikan serta meningkatkan perannya dalam memantau perkembangan anak, serta memberikan pola asuh makan yang baik.
\end{abstract}

Kata Kunci : Perkembangan, Peran Orang tua, Pola Asuh Makan

\begin{abstract}
This study aims to determine the relationship between parental parenting and feeding patterns on toddler development in Puskesmas Kecamatan Pasar Minggu South Jakarta Year 2017. Type of research used in this study is quantitative with Cross Sectional design design approach. The sample taken is the entire total population that is all the mothers of children aged under five Puskesmas Kecamatan Pasar Minggu South Jakarta Year 2017 as many as 107 people. The result of this research shows the parent role variable is obtained $p$ value equal to 0,019, the variable of parenting pattern is obtained $p$ value equal to 0,011 , hence can be concluded that there is relation between parent role and eating pattern with development of balita at puskesmas Kecamatan Pasar Minggu Jakarta Selatan 2017. It is concluded that the role of parents is influential in the development of shaping ability and skill in nurturing and educating their children. While the diet has a relationship with the development of children where parents who have a good level of knowledge about diet will be able to monitor and train the child for optimal development so that if there is a disorder grow kemang on children can be detected early. Recommended for parents, should always provide and increase its role in monitoring child development, as well as provide good eating patterns.
\end{abstract}

Keywords: Development, Role of Parents, Feeding Pattern 


\section{Pendahuluan}

Periode terpenting dalam tumbuh kembang anak adalah pada masa balita. Pertumbuhan dasar yang berlangsung pada masa balita akan mempengaruhi dan menentukan perkembangan anak selanjutnya. Setelah lahir terutama pada 3 tahun pertama kehidupan, pertumbuhan dan perkembangan sel-sel otak masih berlangsung dan terjadi pertumbuhan serabut syaraf dan cabangcabangnya, sehingga terbentuk jaringan syaraf dan otak yang kompleks. Jumlah dan pengaturan hubungan-hubungan antar sel syaraf ini akan sangat mempengaruhi segala kinerja otak, mulai dari kemampuan belajar berjalan, mengenal huruf, hingga bersosialisasi. Pada masa balita, perkembangan kemampuan bicara dan bahasa, kreativitas, kesadaran social, emosional dan intelegensia berjalan sangat cepat dan merupakan landasan perkembangan berikutnya. Perkembangan moral serta dasardasar kepribadian anak juga dibentuk pada masa ini, sehingga setiap kelainan atau penyimpangan sekecil apapun apabila tidak dideteksi apalagi tidak ditangani dengan baik, akan mengeruangi kualitas sumber daya manusia dikemudian hari. ${ }^{1}$

Proses tumbuh kembang bayi dan balita sangat dipengaruhi oleh pemenuhan kebutuhan utamanya. Kebutuhan utama itu dikenal pula dengan istilah triple A, yakni : kebutuhan gizi (asuh), kebutuhan emosi dan kasih sayang (asih), dan kebutuhan stimulasi dini (asah). Ketiganya harus menjadi perhatian serius para orang tua. Kemudian, diberikan secara tepat sesuai tahapan proses tumbuh kembangnya. $^{2}$

Angka kematian balita di dunia mengalami penurunan cukup signifikan dalam 10 tahun terakhir termasuk di beberapa negara miskin.Meski demikian, target Millenium Development Goals yang harus dicapai Tahun 2015 diperkirakan masih jauh.Badan WHO yang mengurusi anak-anak, Unicef mengungkap pada Tahun 2010 tercatat jumlah kematian anak di bawah usia 5 tahun (balita) sebanyak 7,6 juta. Angka ini jauh lebih rendah dibandingkan angka Tahun 1990, yang masih mencapai 12 juta kematian.

Pola asuh orangtua merupakan hal yang paling fundamental dalam pembentukan karakter anak-anaknya. Merujuk pada teori
Urie Bronfenbrenner bahwa individu akan berkembang dalam suatu lapisan-lapisan kondisi sosial kehidupannya yang ada di sekitarnya. Keluarga, terutama orangtua, merupakan lingkungan terdekat pertama yang akan mempengaruhi pembentukan karakter anak. Dampak pola asuh pada anak terhadap pertumbuhan dan perkembangan anak yaitu memberikan stimulasi untuk tumbuh kembang yang optimal.Pola asuh orangtua sangat mempengaruhi pemberian asupan gizi dan nutrisi yang baik pada anak. ${ }^{3}$

Pola asuh makan anak merupakan interaksi orang tua dengan anak; berupa tindakan penyediaan waktu, perhatian, dan dukungan orang tua guna memenuhi kebutuhan fisik, mental, dan sosial. ${ }^{4}$ Kebiasaan makan dapat terbentuk sejak usia balita yang merupakan masa penting dalam kehidupan seseorang karena pada masa inilah ditanamkan sikap, kebiasaan dan pola tingkah laku yang memegang peranan menentukan dalam perkembangan individu selanjutnya. Dalam masyarakat Indonesia, wanita dianggap sebagai pihak yang paling bertanggung jawab terhadap tugas domestik yang mencakup tugas pengasuhan, kesehatan dan pertumbuhan anak. Dari studi yang pernah dilakukan diketahui posisi wanita dalam keluarga turut menentukan keadaan kesehatan dan tumbuh kembang anak karena ini bersangkutan dengan alokasi dana dan waktu. ${ }^{5}$

Mengingat jumlah balita di Indonesia sangat besar yaitu pada tahun 2010 sekitar $10 \%$ dari seluruh populasi yaitu kurang lebih 23,756 juta orang. Dan $9,4 \%$ atau 2,23 juta orang balita yang mengalami penyimpangan, dimana $80 \%$ yang mengalami penyimpangan dapat ditangani di keluarga atau rumah tangga dan $20 \%$ lagi perlu rujukan khusus untuk penanganannya. Hal tersebut disebabkan kurangnya stimulasi dari orang tua terhadap perkembangan anak maka sebagai calon generasi penerus bangsa, kualitas tumbuh kembang balita di Indonesia perlu mendapat perhatian serius yaitu mendapat gizi yang baik, stimulasi yang memadai serta terjangkau oleh pelayanan kesehatan berkualitas termasuk deteksi dan intervensi dini penyimpangan tumbuh kembang. Selain hal-hal tersebut, berbagai factor lingkungan yang dapat mengganggu tumbuh kembang anak juga perlu dieliminasi. Sedangkan di Jakarta Selatan program stimulasi, deteksi dan intervensi dini 
tumbuh kembang anak pada pelayanan dasar belum dapat terlaksana dengan maksimal sesuai harapan dari program Departemen Kesehatan Republik Indonesia (DEPKES RI), sehingga belum terdapat data yang valid mengenai tumbuh kembang balita dan balita yang mengalami penyimpangan. Hal ini disebabkan karena keterbatasan pengelolaan waktu dan keadaan di lapangan.

Penelitian ini bertujuan untuk Mengetahui hubungan pola asuh orang tua dan pola asuh makan terhadap Perkembangan balitadi Puskesmas Kecamatan Pasar Minggu Jakarta Selatan Tahun 2017.

\section{Metode}

Jenis penelitian yang digunakan adalah kuantitatif dengan metode penelitian survey analitik yaitu metode penelitian yang mencoba menggali bagaimana dan mengapa fenomena kesehatan itu terjadi, dengan pendekatan rancangan desain Cross Sectional. ${ }^{6}$

Penelitian dilakukan di Puskesmas Kecamatan Pasar Minggu Jakarta Selatan Tahun 2017 pada bulan Juli.

Populasi dalam penelitian ini adalah keseluruhan objek penelitian yang akan diteliti. $^{5}$ Dalam penelitian ini, populasi yang digunakan adalah seluruh ibu-ibu yang mempunyai anak usia balita di Puskesmas Kecamatan Pasar Minggu Jakarta Selatan berjumlah 107 orang.

Sampel yang diambil adalah seluruh total populasi yang ada yaitu seluruh ibu-ibu yang mempunyai anak usia balita Puskesmas Kecamatan Pasar Minggu Jakarta Selatan Tahun 2017 sebanyak 107 orang.

Validitas adalah suatu indeks yang menunjukkan suatu alat ukur (kuesioner) benar - benar mengukur apa yang akan peneliti ukur. Untuk mengetahui validitas suatu kuesioner dilakukan dengan cara melakukan korelasi antar skor masing - masing variabel dengan skor totalnya. Suatu pertanyaan dikatakan valid bila skor variabel tersebut berkorelasi secara signifikan dengan skor totalnya.Kemudian analisis dilanjutkan dengan uji reliabilitas, reliabilitas merupakan indeks yang menunjukkan sejauh mana suatu alat pengukur (kuesioner) dapat dipercaya atau dapat diandalkan.Uji reliabilitas dilakukan dengan membandingkan nilai $\mathrm{r}$ hasil yang merupakan nilai dari alpha.

Data sekunder dan primer yang terkumpul kemudian diolah melalui tahapan sebagai berikut ${ }^{7}$ :

1. Editing, melakukan pengecekan kuesioner apakah jawaban yang ada di kuesioner sudah lengkap, jelas, relevan dan konsisten.

2. Coding, memberikan kode pada setiap variabel yang diteliti

3. Processing, memproses data dengan cara meng-entry data dari kuesioner ke paket program komputer.

4. Cleaning, kegiatan pengecekan kembali apakah data yang sudah di-entry, ada kesalahan atau tidak.

Data yang diperoleh akan dilakukan analisa secara univariat dan bivariat. Analisis Univariat digunakan untuk mendapatkan gambaran distribusi frekuensi atau besarnya proporsi menurut berbagai karakteristik yang diteliti yaitu variabel independen dan variabel dependen.

Analisis Bivariat digunakan untuk melihat hubungan antara 2 variabel, yaitu variabel independen dan variabel dependen.Digunakan uji Chi-Square karena data pada variabel independen dan variabel dependen merupakan data katagorik.Penyajian data dalam bentuk tabular dan tekstular.

Hasil

Tabel 1. Distribusi frekuensi peran orang tua, pola asuh makan dan perkembangan balita

\begin{tabular}{lcc}
\hline Variabel & $\begin{array}{c}\text { Frekuensi } \\
\text { F }\end{array}$ & $\begin{array}{c}\text { Persentase } \\
\%\end{array}$ \\
\hline Perkembangan & & \\
Penyimpangan & 50 & 46,7 \\
Tidak & 57 & 53,3 \\
Penyimpangan & & \\
Peran Orang Tua & & \\
Tidak Berperan & 44 & 41,1 \\
Berperan & 63 & 58,9 \\
Pola Asuh Makan & & \\
Tidak Baik & 37 & 34,6 \\
Baik & 70 & 65,4 \\
\hline
\end{tabular}

Sumber: komputerisasi software SPSS versi 18 
Tabel 2. Hubungan peran orang tua dan pola asuh makan terhadap perkembangan balita

\begin{tabular}{|c|c|c|c|c|c|c|c|c|}
\hline \multirow[t]{3}{*}{ Variabel } & \multicolumn{4}{|c|}{ Perkembangan } & \multicolumn{2}{|c|}{ Total } & \multirow[t]{3}{*}{ P-value } & \multirow[t]{2}{*}{ OR } \\
\hline & \multicolumn{2}{|c|}{ Penyimpangan } & \multicolumn{2}{|c|}{$\begin{array}{c}\text { Tidak } \\
\text { Penyimpangan } \\
\end{array}$} & \multirow[b]{2}{*}{$\mathrm{F}$} & \multirow[b]{2}{*}{$\%$} & & \\
\hline & $\mathrm{F}$ & $\%$ & $\mathrm{~F}$ & $\%$ & & & & \\
\hline \multicolumn{9}{|c|}{ Peran Orang Tua } \\
\hline Tidak Berperan & 27 & 61,4 & 17 & 38,6 & 44 & 100 & \multirow{3}{*}{0,019} & \multirow{3}{*}{2,762} \\
\hline Berperan & 23 & 36,5 & 40 & 63,5 & 63 & 100 & & \\
\hline Total & 50 & 46,7 & 57 & 53,3 & 107 & 100 & & \\
\hline \multicolumn{9}{|c|}{ Pola Asuh Makan } \\
\hline Tidak Baik & 24 & 64,9 & 13 & 35,1 & 37 & 100 & \multirow{3}{*}{0,011} & \multirow{3}{*}{3,124} \\
\hline Baik & 26 & 37,1 & 44 & 62,9 & 70 & 100 & & \\
\hline Total & 50 & 46,7 & 57 & 53,3 & 107 & 100 & & \\
\hline
\end{tabular}

Sumber : komputerisasi menggunakan software SPSS versi 18

Berdasarkan tabel 1 dapat dilihat bahwa perkembangan Balita di Puskesmas Kecamatan Pasar Minggu Jakarta Selatan yang tertinggi pada perkembangan tidak mengalami penyimpangan sebanyak 57 responden dengan persentasenya $53,3 \%$, peran orang tua yang tertinggi yaitu pada orang tua yang berperan sebanyak 63 responden dengan persentasenya $58,9 \%$ dan Ibu yang pola asuh makannya baik sebanyak 70 responden dengan persentasenya $65,4 \%$.

Berdasarkan tabel 2 dapat dilihat bahwa hasil hubungan antara peran orangtua dengan perkembangan Balita di Puskesmas Kecamatan Pasar Minggu Jakarta Selatan Tahun 2017 bahwa perkembangan tidak menyimpang pada orang tua yang berperan sebanyak 40 responden $(63,5 \%)$, sedangkan perkembangan tidak menyimpang dengan orang tua yang tidak berperan sebanyak 17 responden $(38,6 \%)$. Dari hasil uji hipotesis chi square diperoleh $\mathrm{p}$ value sebesar 0,019, maka dapat disimpulkan bahwa ada hubungan antara peran orang tua dengan perkembangan Balita di Puskesmas Kecamatan Pasar Minggu Jakarta Selatan Tahun 2017. Dari hasil analisis diperoleh nilai OR 2,762 artinya orang tua yang berperan dengan perkembangan balitanya berpeluang 2,7 kali menghasilkan perkembangan balita yang baik atau tidak terjadi penyimpangan dibandingkan dengan orang tua yang tidak berperan.

Hasil analisis hubungan antara pola asuh makan terhadap perkembangan Balita di Puskesmas Kecamatan Pasar Minggu Jakarta Selatan Tahun 2017 bahwa responden yang pola asuh makannya tidak baik dan tidak terjadi penyimpangan pada perkembangan balitanya sebanyak 13 responden dengan persentasenya $35,1 \%$, sedangkan responden yang pola asuh makannya baik dan tidak terjadi penyimpangan sebanyak 44 responden dengan persentasenya 62,9\%. Dari hasil uji hipotesis chi square diperoleh $\mathrm{p}$ value sebesar 0,011, maka dapat disimpulkan bahwa ada hubungan antara pola asuh makan dengan perkembangan Balita di Puskesmas Kecamatan Pasar Minggu Jakarta Selatan Tahun 2017. Dari hasil analisis diperoleh nilai OR 3,124 artinya ibu yang memberikan pola asuh makan yang baik terhadap perkembangan balitanya berpeluang 3,1 kali menghasilkan perkembangan balita yang baik atau tidak terjadi penyimpangan dibandingkan dengan ibu yang tidak memberikan pola asuh makan yang tidak baik.

\section{Pembahasan}

\section{Hubungan peran orangtua terhadap perkembangan Balita}

Dari hasil uji hipotesis chi square diperoleh $\mathrm{p}$ value sebesar 0,019 , maka dapat disimpulkan bahwa ada hubungan antara peran orang tua dengan perkembangan Balita di Puskesmas Kecamatan Pasar Minggu Jakarta Selatan Tahun 2017.

Hasil meta analisis review melalui penelitian yang dilakukan oleh Werdiningsih dan Astarani (2012) peran ibu dalam pemenuhan kebutuhan dasar baik $(87,6 \%)$, cukup $(12,4 \%)$, kurang $(0 \%)$ dapat disimpulkan peran ibu dalam pemenuhan kebutuhan dasar anak sebagian besar baik. Hal ini menunjukan pola asuh pada anak telah memenuhi kebutuhan anak sesuai dengan pertubuhan dan perkembangan anak. Peran ibu pemenuhan kebutuhan dasar terhadap perkembangan anak pra sekolah motorik halus tercapai $(79,9 \%)$, 
tidak tercapai $(20,1 \%)$ CI $95 \% \mathrm{P}$ Value $=$ $0,001<\alpha(0,05)$ correlation coefficient 0,406 dapat disimpulkan ada hubungan antara peran ibu pemenuhan kebutuhan dasar terhadap perkembangan motorik halus anak pra sekolah, bahasa tercapai $(81,5 \%)$, tidak tercapai $(18,5 \%)$ CI 95\% P Value $=0,369<\mathrm{a}$ $(0,05)$ dapat disimpulkan tidak ada hubungan antara peran ibu pemenuhan kebutuhan dasar terhadap perkembangan bahasa anak pra sekolah, personal sosial tercapai $(73,8 \%)$ tidak tercapai $(26,2 \%)$ CI 95\% P Value $=0,001<\mathrm{a}$ $(0,05)$ correlation coefficient 0,400 dapat disimpulkan ada hubungan antara peran ibu pemenuhan kebutuhan dasar terhadap perkembangan personal sosial anak pra sekolah. $^{8}$

Pengaruh keluarga adalah pada sikap dan kebiasaan keluarga dalam mengasuh dan mendidik anak, hubungan orangtua dengan anak, hubungan antara saudara dan lainnya. Keluarga hendaknya menunjang proses pertumbuhan dan pekembangan secara optimal. Termasuk dalam hal ini adalah usia muda ibu, jumlah anak dibawah tiga tahun yang lebih dari satu, ibu atau pengaruh yang tidak kompeten untuk mengasuh, lingkungan hidup yang kotor dan tidak teratur, anggota keluarga yang tidak harmonis, kemiskinan dan ketidakcukupan, prilaku anggota keluarga yang tidak baik.

Peran orang tua dalam pendidikan anak secara tidak langsung memberi kesan yang positif terhadap perkembangan anakanak, diantaranya sikap bersungguh-sungguh dalam aktivitas pembelajaran disamping menunjukkan tingkah laku yang lebih baik dan seimbang. Menurut Jeffrey Glanz parenting secara langsung dan tidak langsung akan memberi kesan yang positif terhadap perkembangan anak prasekolah karena mereka merupakan pendidik di rumah. ${ }^{10}$

Menurut Ireson yang menyatakan bahwa orang tua harus terlibat dengan sebaiknya dalam perkembangan fisik, kognitif, sosial dan emosi anak-anak. Ini karena pada peringkat usia dini adalah peringkat pertama anak dalam alam sekolah, mereka seharusnya sudah dilengkapi dengan kemampuankemampuan yang relevan dan mengagumkan. ${ }^{11}$

Peneliti berasumsi bahwa orangtua berpengaruh dalam perkembangan dalam membentuk kemampuan dan keterampilannya dalam mengasuh dan mendidik anak-anaknya. Kondisi yang diperlukan dalam mendasari pola asuh orangtua adalah situasi yang penuh rasa cinta dan sikap mendukung, pembentukan suasana emosi yang positif dalam interaksi antara anak dan orangtua.

\section{Hubungan pola asuh makan terhadap perkembangan balita}

Berdasarkan hasil penelitian, menunjukkan hasil hubungan antara pola asuh makan dengan perkembangan Balita di Puskesmas Kecamatan Pasar Minggu Jakarta Selatan Tahun 2017 bahwa pola asuh makan yang tidak baik dan tidak terjadi penyimpangan pada perkembangan balitanya sebanyak 13 responden dengan persentasenya $35,1 \%$, sedangkan responden yang pola asuh makannya baik dan tidak terjadi penyimpangan sebanyak 44 responden dengan persentasenya $62,9 \%$. Dari hasil uji hipotesis chi square diperoleh $\mathrm{p}$ value sebesar 0,011, maka dapat disimpulkan bahwa ada hubungan antara pola asuh makan dengan perkembangan Balita di Puskesmas Kecamatan Pasar Minggu Jakarta Selatan Tahun 2017.

Penelitian ini sejalan dengan penelitian Husnah dalam Hubungan Pola Makan, Pertumbuhan dan Stimulasi dengan Perkembangan Anak Usia Balita Di Posyandu Melati Kuta Alam Banda Aceh didapatkan hasil anak dengan pola makan benar maka perkembangan anak normal yaitu $71,4 \%$, sedangkan anak dengan pola makan salah perkembangan dicurigai sebesar $91,7 \%$ hasil uji Chi-Square diperoleh nilai $\mathrm{p}=0,001$ ( $£<$ $0,05)$ ini menunjukkan terdapat hubungan antara pola makan anak dengan perkembangan anak. Hasil penelitian menunjukkan sebagian besar anak dengan pola makan benar cenderung memiliki perkembangan normal dibandingkan dengan anak yang pola makan salah. Berdasarkan analisis data menggunakan uji Chi-Square diperoleh nilai $\mathrm{p}=0,00$ sehingga terdapat hubungan antara pola makan anak dengan perkembangan anak. ${ }^{12}$ Hasil ini sejalan dengan penelitian Rahmaulina dan Hastuti tentang Hubungan pengetahuan ibu tentang gizi dan tumbuh kembang anak serta stimulasi psikososial dengan perkembangan kognitif anak usia 2-5 tahun. 
Tumbuh kembang anak sangat menentukan sumber daya manusia yang berkualitas sehingga kualitas tumbuh kembang anak dapat dipengaruhi oleh factor lingkungan anak terutama orang tua. Ibu yang merupakan orang tedekat dengan anak harus memiliki pemahaman dan pengetahuan yang baik tentang tumbuh kembang anak. ${ }^{13}$

Hal ini sejalan dengan penelitian Wulan pada anak balita di Lombok Timur menyatakan tedapat hubungan antara pertumbuhan dengan perkembangan anak. ${ }^{14}$ Gunawan dkk menyatakan bahwa untuk mencapai tumbuh kembang yang baik diperlukan nutrisi yang adekuat. Makanan yang kurang baik secara kualitas dan kuantitas akan menyebabkan pertumbuhan gizi kurang. Keadaan gizi kurang dapat menyebabkan gangguan pertumbuhan dan perkembangan, khusus pada perkembangan dapat menyebabkan gangguan fungsi dan struktur otak. Keseimbangan antara asupan zat gizi dan jumlah yang dibutuhkan oleh tubuh sangat penting untuk memenuhi berbagai fungsi tubuh.Gangguan asupan gizi yang kurang baik dapat dpengaruhi oleh berbagai faktor. Salah satunya kecukupan pangan. Status gizi yang tidak mencukupi akan mempengaruhi kesehatan anak sehingga rentan terhadap berbagai penyakit. ${ }^{15}$

Menurut penelitian Yulia dkk yang menyatakan bahwa perilaku selama memberikan makan atau pola asuh makan oleh ibu beehubungan positif dan signifikan dengan status gizi pada balita. Dimana jika status gizi balita baik maka pertumbuhan dan perkembangan balita pun akan baik pula. ${ }^{16}$

Peneliti berasumsi pola makan memiliki hubungan dengan perkembangan anak dimana orang tua yang memiliki tingkat pengetahuan yang baik tentang pola makan akan mampu untuk memantau dan melatih anak untuk perkembangan dengan optimal sehingga jika terjadi kelainan tumbuh kemang pada anak dapat dideteksi secara dini.

\section{Kesimpulan}

Perkembangan anak sangat berhubungan dengan peran orang tua dan pola asuh makan. Orangtua berpengaruh dalam perkembangan dalam membentuk kemampuan dan keterampilannya dalam mengasuh dan mendidik anak-anaknya. Kondisi yang diperlukan dalam mendasari peran orangtua adalah situasi yang penuh rasa cinta dan sikap mendukung, pembentukan suasana emosi yang positif dalam interaksi antara anak dan orangtua.

Pola makan memiliki hubungan dengan perkembangan anak dimana orang tua yang memiliki tingkat pengetahuan yang baik tentang pola makan akan mampu untuk memantau dan melatih anak untuk perkembangan dengan optimal sehingga jika terjadi kelainan tumbuh kembang pada anak dapat dideteksi secara dini.

\section{Saran}

Untuk orang tua, harus selalu memberikan serta meningkatkan perannya dalam memantau perkembangan anak, serta memberikan pola asuh makan yang baik agar seluruh balita mendapatkan perkembangan yang optimal sehingga meminimalisir terjadinya penyimpangan perkembangan khususnya pada balita. Bagi tenaga kesehatan, lebih meningkatkan pelayanannya kembali dalam memantau perkembangan balita agar dapat mendeteksi sedini mungkin penyimpangan perkembangan saat usia balita.

\section{Daftar Pustaka}

1. Soetijiningsih. Tumbuh Kembang Anak. EGC: Jakarta; 2012.

2. Evelin PN dan Djamaludin N. Panduan Pintar Merawat Bayi dan Balita. Jakarta: Wahyu Media; 2010.

3. Aisyah S. Kontribusi Pola Asuh Orangtuan Terhadap Tingkat Agresivitas anak. [Jurnal] MEDTEK, Vol. 2 ; 2010

4. Dewi T. Pola Asuh Ibu, Kejadian Diare, dan Pertumbuhan Sampai 4 Bulan pada Bayi yang Mengalami Hambatan Pertumbuhan dalam Rahim. Jurnal Media Medika Indonesia 43 (3): 122-8; 2008.

5. Susanti. Peran Wanita Dalam Pengasuhan Dan Perawatan Kesehatan Anak Balita. Pusat Penelitian Studi Wanita Lembaga Penelitian Universitas Airlangga; 2008.

6. Notoatmodjo S. Metodologi Penelitian Kesehata. Jakarta: Rineka Cipta;2010.

7. Hastono SP. Analisis Data Kesehatan. Depok: Fakultas Kesehatan Masyarakat Universitas Indonesia; 2006.

8. Werdiningsih ATA dan Astarani K. Peran Ibu Dalam Pemenuhan Kebutuhan Dasar Anak Terhadap Perkembangan Anak Usia Prasekolah Role In Meeting The Needs Of Mother On 
Child Development Preschoolers. Jurnal :

9. Fatimah E. Psikologi Perkembangan (Perkembangan Peserta Didik). Pustaka Setia : Bandung; 2006.

10. Hayati F dan Mamat N. Pengasuhan dan Peran Orang Tua (Parenting) serta Pengaruhnya Terhadap Perkembangan Sosial Emosional Anak di PAUD Banda Aceh, Indonesia. Jurnal Buah Hati Vol 1, No 2 (2014): 17-30.

11. Ireson J. Exploring connections between individual and culture at home and school. In Ireson, J. (ed). Learners, Learning, and Educational Activity. New York: Routledge; 2008.

12. Husnah. Hubungan Pola Makan, Pertumbuhan dan Stimulasi dengan Perkembangan Anak Usia Balita Di Posyandu Melati Kuta Alam Banda Aceh.Jurnal Kedokteran Syiah Kuala. Vol. 15 No 2 (2015): 66-71.
STIKES RS Baptis Kediri;2012.

13. Rahmaulina ND dan Hastuti D. Hubungan pengetahuan ibu tentang gizi dan tumbuh kembang anak serta stimulasi psikososial dengan perkembangan kognitif anak usia 2-5 tahun. Jurnal Ilmu Keluarga dan Konsumen. Vol. 1 No 2 (2008) : 1-11.

14. Wulan NR. [Online].; 2012 [cited 2017 Oktober10.From:http://repository.uji.ac.id/100/ sk/I/0/00/00/001015/gizi.NISSA\%250RAHM A\%250 WULAN-8515525419-abstract.pdf.

15. Gunawan G, Fadlyana E, Rusmil K. Hubungan Status Gizi dan Perkembangan Anak Usia 1-2 Tahun. Sari Pediatri. Agustus 2011; 13(2).

16. Yulia C, dkk. Pola Asuh Makan dan Kesehatan Anak Balita pada keluarga wanita pemetik teh di PTPN VIII Pangalengan.2008. diunduh di id.pdfsb.com/jurnal+kesehatan+pada+balita. Diakses pada 10 Oktober 2017. 